\title{
学生視点を取り入れた学科独自の 数学問題集半自動生成システム構築
}

Construction of Semi-automatic Generation System of Mathematical Exercise Book Unique to Department with Student Viewpoint

\author{
井上淳*1 \\ Jun INOUE
}

In this paper, we describe the approach that the systematized the process of student created mathematics exercises and answers and updating the contents of the mathematical exercise book. This effort was made to solve the problem that in general exercise book does not correspond to the learning content of the department or the level of the student. This effort led students to grasp the parts that they did not understand by making mathematics exercises and commentaries, and to review the contents learned in the past. Furthermore, based on the learning items of each subject, it can select necessary mathematics exercises and respond to the rapid change of the departmental situation such as curriculum change. As a result of this effort, the pass rate of mathematics subjects improved and the retention rate of learning contents increased.

Keywords : Teaching Improvement, Basic Education, Self Education, Active Learning, Original Exercise Book

キーワード：教育改善，基礎学力，自己学習能力，アクティブラーニング，独自問題集

\section{1.はじめに}

技術革新やその応用がめまぐるしく進行する社会にお いて，その担い手は理工系の技術者である，それらの技 術者は大学で学んだ内容だけでなく, 社会に出ても学び 続けることが求められている. その一方で, 新しい技術を 学ぶにあたり, 基礎となる科目の正確かつ深い理解も必 要であることから，技術者養成を行う大学には質の高い 教育が求められている. 文部科学省の,「大学における実 践的な技術者教育のあり方に関する協力者会議」におい ても「技術者は，基礎知識や専門知識を実際に用いて社 会・産業の現実問題に応える研究開発や設計，製品の製 造等を行うことが期待されているのであり，技術者の養 成には, 必要な基礎学力を明確にし, 現場, 現物, 現実 を踏まえ，自然科学等の知識を適切に応用できるように する実践的な教育が重要である.」と指摘されている ${ }^{1)}$.

これら専門知識を学ぶ専門科目は多種多様なものがあ るが, その基礎になる部分は数学である. 数学の理解不 足は専門科目の理解に自信が持てないことに直結する. しかし, 理工系を目指す高校生の全てが数学を得意とす るわけではなく, 数学が苦手な学生は毎年一定数入学す る. 数学に関する自信の不足はやる気の減退を招き, 学 習全体に対する意欲を低下させてしまう。学生に聞き取 りを行うと, 数学の学習が進まない大きな原因として, 問題演習に対する無力感が挙げられる。一般的に, 数学

2019 年 1 月 31 日受付

※1 東京電機大学
が得意な学生は「問題演習を行うと理解が深まり, 成績 が上がる」といった成功経験を積むことで, さらに学習 に自信を持って理解を深めていく。これに対し, 数学が 苦手な学生は, その対極に位置する,「問題演習を行って も理解が進まず，成績が悪いまま」という悪い意味での 失敗経験を積むことで, 無力感を抱える要因となる. 問 題演習は学習内容の定着に重要な要素であるため, この 失敗経験が学生の学習意欲低下の大きな要因となる.

この問題は，一般に販売されている問題集では学科独 自カリキュラムや学生のレベルへの対応が難しい上, 解 説が数学の苦手な学生の理解力に対して不十分で, 時に は省略されてしまうことに一因がある. 学生は学科の学 びに必要な分野範囲や難易度範囲が明確にならないこと から, 自らの意思で先に進もうという意欲が湧かない上, 不確実な理解を積み上げていくことで, 問題に対する応 用力が弱くなる.

これらを解決するために「学生が達成度を自覚できる」 「学科で必要な数学を過不足なくカバーしている」「解説 が略されておらず，1行ずつ読めば必ず理解できる」問 題集，言い換えると，「演習をすればするだけ大学での 成績が上がることが保証されている」問題集が必要であ る.ただし，コストと売り上げ数の関係で，出版社に依 頼することは困難である上，教員が全てを作るには膨大 な労力を必要とし, 現実的にはこの問題集の作成は不可 能であった.

一方で, 大学のカリキュラムの関係から, 数学系科目 は学部低学年に集中していることが多く, 専門科目を学 
ぶ高学年になるまでに学習した内容が不確かになってし まうことが専門科目の理解を困難にする要因である.「知 識の獲得」から時間的な経過の後「知識の活用」ではな く,「知識の獲得」に平行した「知識の活用」が深い学び を生起させるということも指摘されている ${ }^{2)}$.これに対 しては，定期的に復習を行うことが必要であるが，カリ キュラムとしてそれを行わせることは難しい. 長期休暇 等の際に問題演習を課す手法も考えられるが，正解が決 まっている一般的な課題を出しても, 必ずしも学生全員 が毎回勉強をするわけではないという調査結果も存在す $ろ^{3)}$. そのため, 問題演習を行う一般的な課題を出すこ とで学科全体の数学の理解度を向上させることは困難で あると考えられる。

そこで，これらの問題を全て解決するため, 著者の所 属する東京電機大学未来科学部ロボット・メカトロニク ス学科では, 学生が問題・解説作成に参加する形で数学 問題集を毎年更新することで，常に最新の学科カリキュ ラムに必要な演習問題を学生に提供し, かつ, 問題作成 という形で正解が一つに定まっていない復習課題を課す 新しい手法を実施している.

本手法の特徵の一つとして, 学生が試験問題を作成す るMIT（マサチューセッツ工科大学）の講義・学科試験 で用いられている「MIT方式」交を応用していることが 挙げられる. 学生が数学の演習問題・解説作成を行い, その内容を上の学年の学生がチェックして良問を選択す る手法をとっている.さらに，もう一つの特徴として, その良問の中から教員が問題集に追加する問題を選択す る際, 学科カリキュラムや学習到達度試験（アチーブメ ントテスト）の結果を用いて, 現在の学科・学生の状況 に合わせた問題を選択していることが挙げられる. また, 特定の科目を受講している学生だけでなく, 全ての学科 所属学生が問題・解説作成に参加することで, 学科全体 の学生の教育改善に繋がっている.

問題集に対する学生の満足度は非常に高く，講義範囲 外の問題や興味のある分野の問題を自ら探して取り組む など, 積極的な自主学習に活用されている. その効果と して数学科目の単位取得率の向上や学習内容の定着率の 上昇が得られた。

以下，2章で手法の詳細について述べ，3 章でその成 果について述べる.

\section{2. 問題集更新手法}

本取組みでは，年間を通して，図 1 に示すような 4 つ のブロックからなるサイクルを回して問題集を利用して いる. 本章では問題集の更新について, 問題・解説作成, 良問選定，採用する問題の選定，学科カリキュラムと連 動した問題集の利用の 4 つに分け，具体的な手法とその ねらいについて述べる。

\section{1 問題 - 解説作成}

問題および解説の作成においては，MIT方式を応用し た. MIT方式とは, マサチューセッツ工科大学で実施さ れ始めた試みで, 講義を受ける学生が自ら試験問題を作 成するものである，学生が試験問題を作成する中で，わ

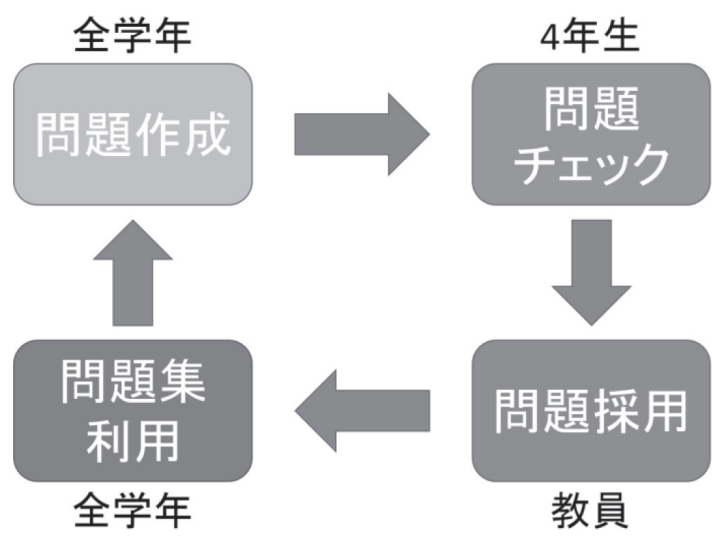

図 1 問題集更新手順

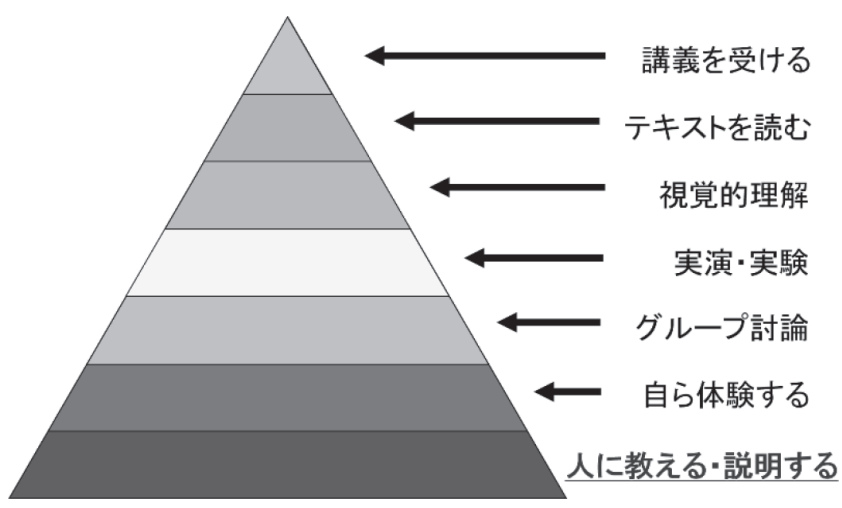

図 2 学習ピラミッド

からない部分を明確化させることや，解説を作ることで 理解が進むという教育効果があり, 図 2 に示すような, 学習ピラミッドの最下段にあたる「人に教える・説明す る」ことに繋がることから, 理解の深化を目指したもの である5).

具体的には, 夏季課題として 1 年生には高校数学と大 学数学の基礎範囲, 2 年生には微積分学と線形代数の範 囲など, 各学年のカリキュラムで一年間に学習した内容 に関して学科から範囲を指定し, 問題作成を課す。また, 問題作成だけでなくその解説を学生が自ら作成するとい う方法を取った。

この手法のねらいとしては，一年間の勉強の振り返り を自然に行い, 数学知識を確実に身につけることと, 一 般的な問題演習では得られない, 問題構造の把握による 理解の深化を目指した。学生は問題を作成する際, ゼロ から作成することは稀であり, 教科書や既存の問題を参 考にすることがほとんどである. ただし, 単なる解答で はなく，他人が理解できる解説の作成も同時に課してい るため, 既存の問題の数字を適当に変えただけで提出す るということが出来ないようになっている。すなわち, 解が得られる問題を作成し, 友人と互いの問題について ディスカッションする必要があることから, なるべくわ かりやすい解説を作成するようになる。

さらに, 解説を作成する手間を考えて, 綺麗な解答にな るように調節したり，途中の式変形が複雑にならない問 題の作成を試みる学生が多い。ここで学生は, 問題条件 
と解答の関係性を把握することができる。たとえば微分 方程式であれば，係数や初期条件を変化させた際に，最 終的な解答に与える影響等が試行錯誤的に理解できる. これは, 問題をパターン分けして一定の解き方に沿って 解答するだけでは得られない, 問題の本質に一歩近づい た内容の理解であり，専門科目で必要になる，実問題へ の応用にも大きく貢献する.

これらの内容はアクティブラーニングの中の「Student-Gnenerated Questions」および「Peer teaching」に 当たり ${ }^{6)}$ ，自ら学びを深めるほか，授業時間外に学生同 士で勉強を学ぶ習慣づけができる.

\section{2 良問選定}

学生によって夏季休業中に作成された問題と解説は, 質的保証を図るため，そのチェックと良問選択を行う必 要がある.MIT方式では教員が試験問題のチェックと選 定を行うのが一般的であるが，本システムでは問題のチ エックを行うにあたり, 学生に取り組ませることとして いる。本学科の取り組みとして，月曜から金曜までの夕 方90分間，学部 4 年生が質問に来る下級生に勉強を教え る，よろず相談室というものがある。その担当学生が, 問題のチェックと良問の選定を，質問対応をしていない 時間に行う。この際, チェック項目として, 表 1 に示す 内容を指示している.

また，選定した中で，解説に不足があればその部分を 補うところまでを学部 4 年生の作業内容としている。そ のため, 修士に進む直前の段階でそれまでの数学知識を 復習することになり，高学年で低下しがちな数学力を再 獲得することができる。また，自分が低学年の頃に理解 が難しかった問題など，学科の学びに役に立つ問題を学 生目線で選定することが可能である.

また，問題集作成後，次年度前期には，学年が変わっ て入れ替わったよろず相談室の学生に，問題集と回答集 を渡し，表 1 に示すように追記された解説の間違いの有 無や, 問題の分類が適切かどうかなどについて再度確認 させる．このことにより，後期に問題をチェックするた めの準備を行う事が可能である。

\section{3 採用する問題の選定}

(1) 専門科目につながる問題の採用

学科のカリキュラムをカバーする問題集を制作するた め, 機械・電気・情報・制御・専門数学すべての分野に おいて, 各科目の担当教員から表 2 に示すような講義に 関連する数学学習項目（キーワード）を収集している. このキーワードとその科目の学習内容に沿って, 学部 4 年生によって選定された良問の中から，問題集に追加す るものを絞り込むことが可能である.さらに, キーワー ドと併せ，学生にとって理解の難しい事項も各科目担当 から聞き取りを行うことで問題選定に反映させることが できる。

(2) 学生の苦手克服のための問題の採用

(1) で挙げた問題以外に，学生全体の苦手部分の底上 げを目的として，アチーブメントテスト（学習達成度試 験）の結果を用いて問題を採用する。アチーブメントテ ストとはロボット・メカトロニクス学科・専攻の全員が
表 1 学生による問題のチェック項目

\begin{tabular}{|l|l|}
\hline & \multicolumn{1}{|c}{ チェックタスク } \\
\hline \multirow{4}{*}{ 後期 } & 1)問題に誤りがないか \\
\cline { 2 - 3 } & (2)解説が分かりやすいか \\
\cline { 2 - 2 } & (3)学生視点で見て学科の学びに役に立つか \\
\cline { 2 - 2 } & (4)自分が過去につまずいた問題かどうか \\
\cline { 2 - 2 } & 5)問題を単元ごとに分類 \\
\hline \multirow{2}{*}{ 前期 } & 1)後期に追加された解説に間違いがないか \\
\cline { 2 - 2 } & (2)問題の分類は適切かどうか \\
\hline
\end{tabular}

表 2 各専門科目の関連数学学習項目 (一部抜粋)

\begin{tabular}{|c|c|c|c|}
\hline 分野 & 科目名 & 学習キーワード & $\begin{array}{l}\text { 関連数学 } \\
\text { 学習項目 }\end{array}$ \\
\hline \multirow{2}{*}{ 機械 } & 材料力学 & $\begin{array}{l}\text { 応力とひずみ, フックの法則, } \\
\text { ポアソン比, はり, 剪断力, } \\
\text { 曲げモーメント }\end{array}$ & 微分 - 積分法 \\
\hline & $\begin{array}{c}\text { 機械製図 } \\
\text { II }\end{array}$ & $\begin{array}{l}\text { CAD, 寸法公差, はめあい, } \\
\text { 幾何公差, 表面性状, 枕じ, } \\
\text { 歯車, 継手, キー・キー溝 }\end{array}$ & $\begin{array}{l}\text { 微分·積 分法, } \\
\text { 確率分布, 数列 }\end{array}$ \\
\hline \multirow[b]{2}{*}{ 電気 } & $\begin{array}{c}\text { 電気回路 } \\
\text { II }\end{array}$ & $\begin{array}{l}\text { 複素数, 正弦波のフェーザ, } \\
\text { インピーダンス }\end{array}$ & $\begin{array}{l}\text { 三角関数, 複素 } \\
\text { 数, 複素数平面, } \\
\text { 微分・積分 }\end{array}$ \\
\hline & 信号処理 & $\begin{array}{l}\text { 正弦波, フーリエ級数展 開, } \\
\text { 複素フーリ工級数展開, OFT, } \\
\text { スペクトル解析 }\end{array}$ & $\begin{array}{l}\text { 三角関数, 複素 } \\
\text { 数, ベクトル, } \\
\text { 微分法·積分法, } \\
\text { 確率分布 }\end{array}$ \\
\hline 制御 & $\begin{array}{c}\text { 制御工学 } \\
\text { I }\end{array}$ & $\begin{array}{l}\text { システムの応答, ブロック線図, } \\
\text { 周波数応答と周波数伝達関数, } \\
\text { ゲインと位相, ボード線図, } \\
\text { 安定性 }\end{array}$ & $\begin{array}{l}\text { 指数関数·対数 } \\
\text { 関数, 三角関数, } \\
\text { 複素数, 微分法. } \\
\text { 積分法 }\end{array}$ \\
\hline 情報 & 情報理論 & $\begin{array}{l}\text { 情 報 量, エントロ ピー, } \\
\text { 情報源と通信路, 情報源符号化, } \\
\text { 通信路符号化 }\end{array}$ & $\begin{array}{l}\text { 集合, 指数 } \cdot \text { 対 } \\
\text { 数関数, 確率 }\end{array}$ \\
\hline
\end{tabular}

年に一度同時期に受験する試験で, 英語, 数学と専門科 目の学修到達度を測るものである。どの学年も同じ試験 内容であり, 自分の学力が全学年でどの程度の位置にあ るかを把握することができる. 数学の試験は毎年, 11分 野に分けて問題を作成しており, その中で学生の正答率 の低い分野の問題を，2で選定された問題の中から重点 的に問題集に追加することで，学生のレベルにあった問 題集の構築を図り, 問題集の陳腐化を防ぐことができる. この手法で問題を追加することで, 高校の学習指導要領 の変化に伴う新入学生の数学知識の変化など, 学生を取 り巻く教育環境にも素早く対応することが可能である.

また，問題の採用を教員が実施することで，最終的な 問題のチェックも兼ねている.

\section{4 学科カリキュラムと連動した問題集の利用}

上記段階を経て完成した問題集を，推薦入試等で合格 した学生には事前送付し, 自分の所属する高校で 3 月末 までに学ぶ範囲の問題を全て解答して入学時に提出させ る.このことにより, 一般入試で合格して入学してくる 学生との学力格差を縮小させることを目指す.

また，4月以降は全学生に配布し，専門科目の進行に 合わせて問題を解かせることで, 数学力の底上げを図る. また，学生にはどの問題を解いても学科の学びに役に立 つことを伝えてあるため, 授業外でも学習の役に立てる 
ことができる.

講義で主に利用するのは 1,2 年生の通期で行われる メカトロニクスワークショップという科目に打ける数学 演習である。この科目は学科の学びに必要な基礎知識を オムニバス形式で学ぶ講義で, 2 週に 1 度, 1,2 年生交 互に数学演習回を設けている. その中で, 数学科目の進 度に合わせて解く問題を設定したり，他専門科目の担当 教員から次の週に学ぶ事項に関連する演習問題の依頼を 受けて学生に解かせるなど, 学科カリキュラムと有機的 に結びついた弾力的な運用ができている，また，この講 義中に学生の苦手な問題を把握することで次年度以降の 問題構成に活かすことができる。これらは，市販の問題 集では行うことが不可能な運用の仕方であると考えられ る.

\section{3. 問題集実施による成果}

本取組みは2013年から改良しながら実施しており，初 年度に 2 年生として講義で問題集を利用し始めた学生が 2018年 3 月に修士 2 年生として卒業した。 そこで, 本手 法実施による教育改善効果の評価を行った.

本手法を採用したことにより, 進級率の劇的な向上, 学生の自学自習意欲の向上, 学科専門科目カリキュラム との連動, 数学系科目の理解度上昇, 数学知識定着率の 向上の 5 つの効果が得られた。これらは, 本取り組みの 元となったMIT方式にはなかった効果であり, 継続的に 本手法を実施することによる効果は非常に高いものと考 えられる。

\section{1 進級率の向上}

ロボット・メカトロニクス学科は新設されて数年間, 4 年卒業率がやや低かったが, 現在では学部の平均値と 同程度まで向上した.これは学生の数学力の改善により, 数学科目だけでなく, 専門数学, 数学が基礎となる専門 科目も含めて理解が深まり, 全体の単位取得率が向上し たことによる効果である，さらに，本システムの中で全 学生に問題・解説を作成させることで, 学生が学習内容 の振り返り・理解の深化を行うことができたことも理由 だと考えられる.この結果から, 本手法が数学の苦手な 学生に対する効果が大きいことがわかる.

\section{2 学生の自学自習意欲の向上}

本問題集の利用に関して, 講義で使用している 1,2 年生計 232 名に対してアンケートを行ったところ, $88 \%$ が 「ロボット・メカトロニクス学科数学問題集が使いやす い」と回答した，さらに，講義で指定された範囲外の問 題も自発的に解いたという回答が $43 \%$ あり，その中でも 特に, まったく未学習の中から自分の興味の向く問題を 自ら探して解いたという回答も $16 \%$ あった．学生の問題 集に対する満足度が高いことと, 自学自習意欲が高まっ ていることが本システムの成果として挙げられる. その ため, 学年が上がっても講義内容を忘却せず，より高い 位置からのスタートを切ることができる.この結果から， 本問題集が数学の苦手な学生だけでなく, 数学の得意な 学生に対しても学びの役に立っていることがわかる. 学 生からの意見として「専門科目の授業に入る前に必要な
知識を再確認することができた」「これをやれば学科に 必要な数学知識が手に入るということがわかったので, 安心して問題集を解くことができた」などが得られた。 一方で, 問題をチェックする側の学部 4 年生からは「忘 れていた部分が思っていたよりも多く, チェックをする ことで自分たちのほうが勉強になった」「解説の上手な 学生, 下手な学生両方の作った問題を見ているうちに, どうやれば相手にうまく教えられるかが理解できた」な どの意見が得られた。

\section{3 学科専門科目カリキュラムとの連動}

本問題集を講義中に用いる科目のメカトロニクスワー クショップは, 1 年生と 2 年生の前期と後期に開講され る. その中で数学演習を実施しており, 専門科目の講義 計画にあわせて関連する演習問題を配置するなど, 柔軟 な組み立てを行っている。 これにより, 学生が数学系科 目で学んだ問題に対する解法を, 専門科目で学ぶ応用的 な問題に適用するための架け橋の役割を果たす事ができ た.これは, 問題更新時の各教員からのキーワード収集 と, キーワードおよび担当教員への聞き取りの結果を用 いた問題の配置によって実現したものであり，学科カリ キュラム全体の連動を図り, 学びの底上げを行うことが 可能となった.

\section{4 数学系科目の理解度上昇}

本問題集利用の短期効果として， 1 年生の数学科目で ある線形代数学 I と微分積分学および演習 I の不合格者 数の推移に着目した. 表 3 および図 3 に示すように, 2012 年度の不合格者率は線形代数学が $28.0 \%$, 微分積分学お よび演習 I が $12.8 \%$ だったが，本取組みを始めた 2013 年 度から順調に下がり続け, 2017年度には線形代数学は 8.7 $\%$, 微分積分学および演習 I は $4.7 \%$ と大幅に減少した。 この数字には休学者や体調不良で試験を受けられなかっ た学生なども含まれているため, 実数はさらに小さいも のになる.この結果から, 入学後すぐの 1 年生に対して,

表 3 数学系科目 1 年次終了時点での不合格者数

\begin{tabular}{|c|r|r|r|r|r|r|}
\hline 入学年次 & 2012年 & 2013年 & 2014 年 & 2015年 & 2016年 & 2017年 \\
\hline $\begin{array}{c}\text { 微分積分学 } \\
\text { およひ演習 I }\end{array}$ & 17 & 17 & 11 & 5 & 7 & 6 \\
\hline 線形代数学 I & 37 & 25 & 23 & 19 & 18 & 11 \\
\hline 学生総数 & 132 & 138 & 129 & 143 & 125 & 127 \\
\hline
\end{tabular}

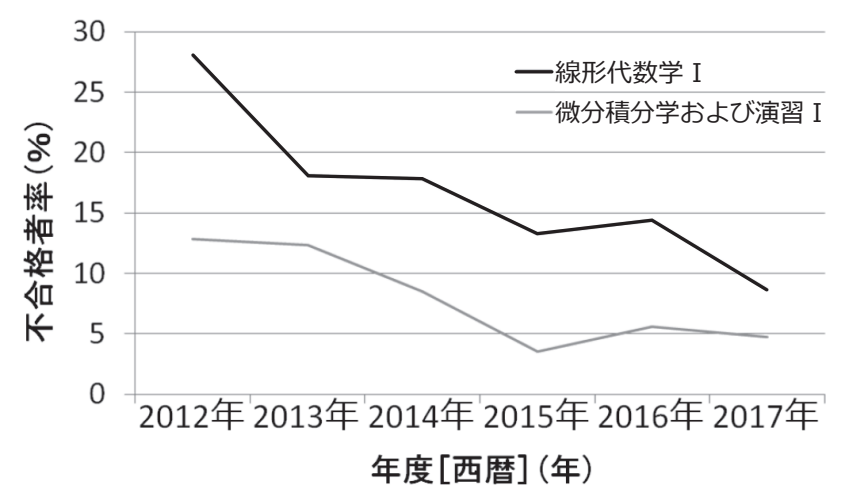

図 31 年生数学科目学生数に占める不合格者の割合 
表 4 学部 1 年生と修士 1 年生の平均点と比率

\begin{tabular}{|c|c|c|c|c|c|c|}
\hline 試験年度 & 2012 年 & 2013 年 & 2014 年 & 2015年 & 2016年 & 2017年 \\
\hline 学部 1 年生 & 45.4 & 39.5 & 30.0 & 25.5 & 30.5 & 30.6 \\
\hline 修士 1 年生 & 46.8 & 39.9 & 30.9 & 26.6 & 36.7 & 40.5 \\
\hline 成績比率 & 1.03 & 1.01 & 1.03 & 1.04 & 1.2 & 1.32 \\
\hline
\end{tabular}

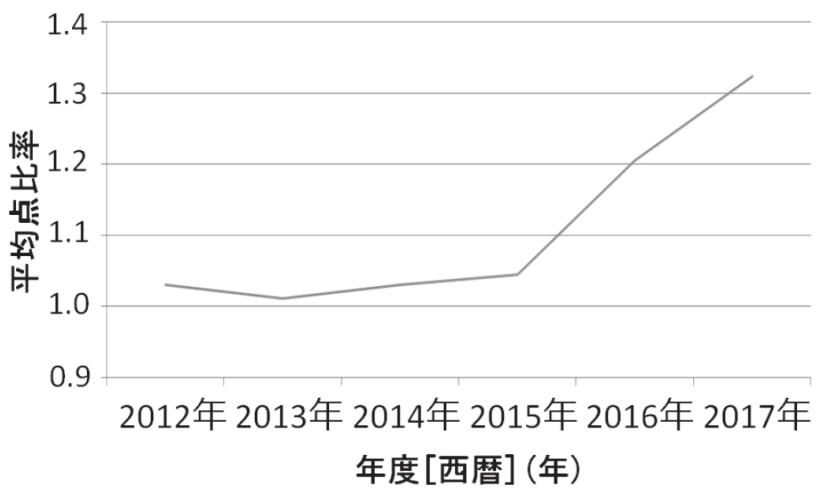

図 4 修士 1 年生と学部 1 年生の平均点比率

入学前教育とこの問題集の利用が教育改善として有効に 働いていることが明らかになった.

\section{5 数学知識の定着率上昇}

長期効果として, 本学科で実施しているアチーブメン トテストの結果に着目した。 アチーブメントテストの問 題は毎年変わり，平均点や難易度を一定にすることはで きていないため, 修士 1 年の数学平均点を学部 1 年生の 数学平均点で割った成績比率に着目したところ, 年々上 昇してきていることがわかった，表 4 抢よび図 4 に示す ように, 2012 年には修士 1 年生の数学平均点は学部 1 年 生の平均点の 1.03 倍であり, 学習の効果が見られなくな っていた，上昇を続け，2017年には1.33倍まで向上した. これは, 一般的には高学年で忘却しがちな, 低学年で学 んできた数学の基礎知識が定着することで, 解答できる 問題が増加していることを意味している。 この基礎知識 の定着は問題・解説のチェックで得られることの教育効 果も要因であると考えられるため, 問題のチェックを行 う学年を拡大することで, 更なる効果が得られることが 予想される。

\section{6 問題・解説作成の教育的効果}

本取組みの中の, 問題・解説作成の部分の教育効果を 計るため, 課題を実施してから半年後に追加アンケート を実施した。

「問題・解説の作成による新しい発見があったか」の 問いに対しては, $65 \%$ が新しい発見があったと回答した. 中でも 1 年生に新しい発見があったという回答が多く, 学ぶ場が高校から大学に変わって勉強の仕方がわからな くなっていた学生にとって有意義であったというコメン 卜などが得られた.「数学の夏季課題として,一般的な問 題演習と問題・解説の作成課題はどちらが勉強になるか」 の問いに対しては， $60 \%$ が問題・解説の作成の効果が高 いと答えた，問題・解説の作成も勉強になる一方で, 問 題演習も平行して実施することが必要であると感じてい

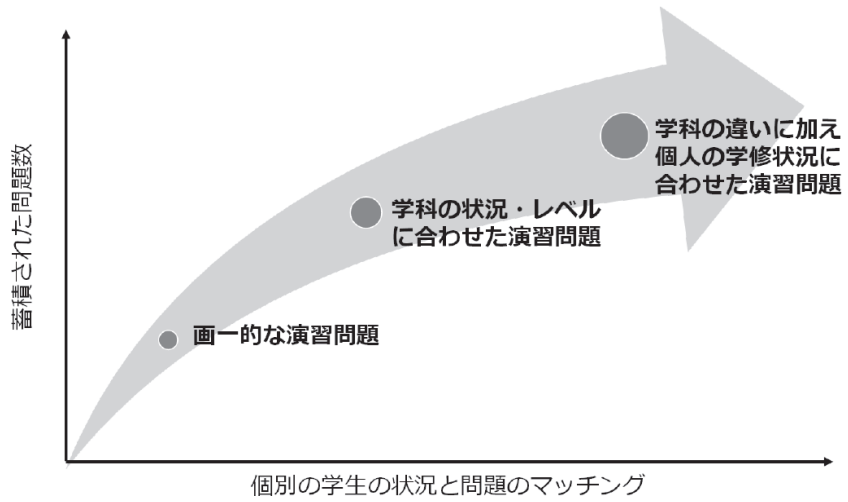

図 5 個人にマッチした演習問題集の構築

ることが伺える。「作成問題作成だけでなく,解説を作成 したことによる学びへの効果」については，92\%が解説 を追加で作成することが学びへの効果を高めると回答し た. 自由記述では「自分が理解できていなかったことを 認識することができた」「問題・解説作成の際に昔のノー 卜を見返したら記憶から抜け落ちている知識が思ったよ り多いことに気づいた」「解説を作成することで論理的 に説明する能力が付いた」というコメントが得られた.

これらの回答から, 問題演習だけではなく, 自らの手 で問題・解説まで作成することで, 知識の振り返りを行 う事ができ, 数学の学びに対して有効だと学生が感じて いることが明らかになった.

\section{4.まとめ}

数学力強化を目指した問題集構築システムとして, MIT方式を応用し, 学生自身が問題掞よび解説を作成・ 良問の選定を行うことで, 学科・学生の状況に柔軟に即 応可能な問題集更新システムを構築した。その結果とし て, 学生が安心して問題集を利用することができるよう になった上, アクティブラーニングや学習内容の振り返 りを自然と行う事が出来るようになり, 自学自習意識の 向上・成績の向上・進級率の向上と, 数学系科目だけに とどまらない大きな教育改善効果を生んだ。

さらに, 本業績はその, 組織ごとに学生たちによる問題 作成によって独自の問題集を構築するという特色から, 学生のレベルによらず, また中学・高校・大学のあらゆる 学校組織での数学力の強化・専門科目の基礎となる数学 知識の定着に利用できることにその大きな価值がある. さらに大切な点として, 普通の方法では教員の負荷が大 きく実現できなかった各組織独自の問題集構築が, 本手 法を用いることで現実的になったことが本取組みの一番 の効果であると考える.

今後の展望として, 現在学部 4 年生のみで実施してい る問題のチェックを学生全体で相互に実施するなど, 教 育課程としての取組みをより強化し, 数学知識の定着力 上昇をより確かなものにしていく，さらに，図 5 に示す ように, 現在の各組織へマッチするシステムから, 個人 ヘマッチするシステムへの応用を検討している，今まで は画一的かつ, 数年間変わらない演習問題が当たり前で 
あった。しかし，本取組みでは学科の状況と学生のレベ ルに合わせた演習問題集を作ることに成功した，今後は コンピュータを使うなどして, 問題の利用状況・解答状 況の収集をすることで個人の学習状況に合わせた問題の 提示が可能なシステムへのアップグレードを検討してい る. 例えば, 個別の学生の解答状況を集めることによっ て, ある問題群が苦手な学生は別の問題群も苦手である という事前情報が構築できる. 新たに問題を使用する学 生の解答状況から，一人ごとに適切な問題を提示するソ フトウェアを構築するなど, 情報工学的アプローチの適 用を目指す。

\section{参 考 文 献}

1）文部科学省：大学における実践的な技術者教育のあ り方，大学における実践的な技術者教育のあり方に 関する協力者会議, 平成 22 年 6 月 3 日, Webページ, http://www.mext.go.jp/b_menu/shingi/chousa/ koutou/41/index.htm, 参照日：2018-1-30

2 ) 谷口哲也 : 高次のアクティブラーニングの評価, 工 学教育, $61-3$, p.10-13, 2013

3 ) 吉田 博, 戸川 聡, 金西計英 : 大学の授業における 学生が授業外学習を行う要因, 日本教育工学会論文 誌, 35巻Suppl.号, pp.153-156, 2011
4 ）青木雅子, 奥野順子, 関森みゆき, 日沼千尋, 櫻田章 子：学生が試験問題を作成するアクティブラーニ ングの展開, 東京女子医科大学看護学会誌, $11-1$, pp. $54-60,2016$

5 ）土持ゲーリー法一 : ラーニング・ポートフォリオー 学習改善の秘訣, 東信堂

6 ) Jenny A. Van Amburgh, John W. Devlin, Jennifer L. Kirwin, and Donna M. Qualters : A Tool for Measuring Active Learning in the Classroom, American Journal of Pharmaceutical Education, 71 $-5,2007$

著 者 紹 介

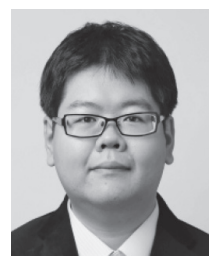

井上 淳

学 歴 2013年 早稲田大学大学院卒

学 位 博士 (工学)

所 属 東京電機大学 未来科学部 ロボット・メカト ロニクス学科 助教

専 門 福祉工学・情報工学

所属学会 日本機械学会, 電気学会, IEEE, 生活支援工 学会他

連絡先 inoue.jun@fr.dendai.ac.jp 